\title{
Bakti Sosial di Lembang Marinding dan Kelurahan Lemo, Kecamatan Mengkendek, Tana Toraja
}

\author{
Nasrudin Andi Mappaware ${ }^{1,3^{*}}$, Syamsu Rijal ${ }^{1,3}$, M. Akil ${ }^{1}$, Wirawan Harahap ${ }^{1,3}$, Armanto \\ Makmun $^{1,2}$, Shofiyah Latief ${ }^{1,3}$, Arni Isnaini Arfah ${ }^{1,3}$, Nurfadhillah Khalid ${ }^{1}$, Rezky Pratiwi \\ L.B ${ }^{1}$, Utomo Andi $\mathbf{P}^{1,3}$, Andi Masdipa ${ }^{1}$, Ryan Charmy Pratama ${ }^{3}$, Andi Dirhan Takdir ${ }^{3}$, \\ Rahmawaty Kurnia $^{4}$, Muh. Fuad Alamsyah ${ }^{4}$, Muhammad Irsan ${ }^{5}$, Asro Akjuma Pratama ${ }^{6}$ \\ ${ }^{1}$ Program Studi Pendidikan Dokter Fakultas Kedokteran UMI \\ ${ }^{2}$ Unit Penelitian dan Pengabdian Pada Masyarakat (UP3M) Fakultas Kedokteran UMI \\ ${ }^{3}$ The Associatio of Medical Docter Of Asia (AMDA) Indonesia \\ ${ }^{4}$ Asian Medical Students Association (AMSA) UMI \\ ${ }^{5}$ Dewan Mahasiswa Profesi (DMP) Fakultas Kedokteran UMI \\ ${ }^{6}$ Badan Eksekutif Mahasiwa (BEM) Keluarga Besar Mahasiswa Fakultas Kedokteran \\ (KBMFK) UMI
}

*Email Korespondensi: nasruddin@umi.ac.id

Telp: +62 812-4257-274

\begin{abstract}
ABSTRAK
Bakti sosial memberikan perubahan dalam peningkatan penyediaan layanan kesehatan dan kualitas kesehatan pada lingkungan masyarakat. Pendekatan ini sangat baik untuk mampu membangun keterampilan dan empati untuk saling membantu di masyarakat. Kegiatan ini merupakan kegiatan sosial untuk memberikan pelayanan kesehatan masyarakat melalui sirkumsisi, pemeriksaan kesehatan umum, pemeriksaan kandungan USG, dan promosi kesehatan juga meningkatkan clinical skill dari anggota AMSA UMI khususnya preklinik dalam kelakukan sirkumsisi. Waktu pelaksanaan tanggal 12 bulan September 2019 di di Desa Binaan UMI, Lembang Marinding dan Kelurahan Lemo, Kecamatan Mengkendek, Tana Toraja. Metode yang digunakan pada pelatihan ini merupakan pelatihan partisipatif, yakni anggota AMSA-UMI ikut aktif dalam kegiatan pengabdian sosial. Jenis kegiatannya ialah sirkumsisi(sunatan) terdiri dari 36 orang peserta, rata-rata umur 12 tahun; pemeriksaan kesehatan umum terdiri 164 orang peserta, rata-rata umur 54 tahun; pemeriksaan kandungan USG terdiri dari 23 orang peserta, umur rata-rata 45 tahun; dan promosi kesehatan untuk masyarakat desa binaan terdiri dari 100 orang peserta. Kegiatan bakti sosial ini sebagai penentu sosial kesehatan masyarakat dan juga dapat menjadi wadah bagi mahasiswa untuk dapat berinteraksi secara langsung dengan masyarakat sehingga dapat merealisasikan langsung ilmu yang telah didapatkan dalam perkuliahan ke masyarakat.
\end{abstract}

Kata Kunci: Bakti sosial; kesehatan masyarakat; promosi kesehatan

\begin{abstract}
Social service provides a change in improving the provision of health services and the quality of health in the community environment. This approach is very good to be able to build skills and empathy to help each other in the community. This activity is a social activity to provide public health services through circumcision, general health checks, ultrasound examination, and health promotion as well as improving clinical skills of AMSA UMI members, especially preclinical in circumcision behavior. The implementation time was on September 12, 2019 in the fostered village of UMI, Lembang Marinding and Lemo Village, Mengkendek Subdistrict, Tana Toraja. The method used in this training is participatory training, where AMSA-UMI members participate actively in social service activities. The type of activity is circumcision (circumcision) consisting of 36 participants, the average age of 12 years; general health examination consisting of 164 participants, with an average age of 54 years; examination of USG contents consisted of 23 participants, the average age of 45 years; and health promotion for the target village community consisting of 100 participants. This social service activity as a social determinant of public
\end{abstract}


health and can also be a forum for students to be able to interact directly with the community so that they can realize the knowledge directly obtained in lectures to the community.

Keywords: Social service; public health; health promotion

\section{PENDAHULUAN}

Era globalisasi mendorong setiap bangsa di dunia untuk memiliki sumber daya manusia yang berkompeten sehingga tercipta kemajuan di berbagai aspek kehidupan bangsa tersebut. Dalam rangka menyiapkan kompetensi tersebut, proses pendidikan dan pelatihan yang berkelanjutan menjadi prioritas utama. Begitu pula, dengan sumber daya manusia dalam bidang kesehatan dalam hal ini mencakup mahasiswa kedokteran. Walaupun belum mendapat gelar sebagai seorang dokter, mahasiswa kedokteran butuh sarana untuk menerapkan teori yang didapatkannya di bangku perkuliahan dalam rangka menyiapkan kompetensinya untuk menjadi seorang dokter kelak. Selain itu, mahasiswa kedokteran juga diharapkan dapat mengetahui fungsi dari profesinya kelak, yaitu sebagai pengabdi masyarakat.

Kegiatan bakti sosial sebagai penentu sosial kesehatan masyarakat dan juga dapat menjadi wadah bagi mahasiswa untuk dapat berinteraksi secara langsung dengan masyarakat sehingga dapat merealisasikan langsung ilmu yang telah didapatkan dalam perkuliahan ke masyarakat.(1) Melalui organisasi maka seseorang bisa dibentuk karakternya dan dikembangkan kemampuan dalam dirinya. $(2,3)$ Namun, untuk sampai pada tingkat pengembangan kemampuan dan membentuk karakter yang baik, perlu usaha keras yang melibatkan tidak hanya peserta yang bersangkutan namun juga pihak lain, untuk mencapainya.(4,5) Asian Medical Students' Association (AMSA) UMI adalah organisasi eksternal nonpolitik, non-profit di Fakultas Kedokteran UMI. Sebagai salah satu wadah pengembangan bakat dan kemampuan, AMSA UMI bertanggung jawab dalam pengembangan diri dan pembentukan karakter yang baik bagi anggotanya yang sesuai dengan filosofi AMSA UMI sendiri, yaitu Knowledge, Action, Friendship, dan Religious. Untuk memenuhi tanggung jawab tersebut, AMSA UMI akan mengadakan kegiatan pengabdian kepada masyarakat berupa bakti sosial: promosi kesehatan, sirkumsisi, pemeriksaan kesehatan umum dan pemeriksaan USG kehamilan program kerja AMSA UMI di Desa Binaan UMI, Lembang Marinding dan Kelurahan Lemo, Kecamatan Mengkendek, Tana Toraja demi pengembangan sumber daya manusia dalam kepengurusan AMSA UMI dimasa yang akan datang.

\section{METODE PELAKSANAAN}

\subsection{Solusi dan Target Luaran :}

Kegiatan ini sebagai kegiatan sosial untuk memberikan pelayanan kesehatan kepada masyarakat melalui sirkumsisi, Pemeriksaan kesehatan umum, pemeriksaan kandungan USG, serta promosi kesehatan juga meningkatkan clinical skill dari anggota AMSA UMI khususnya preklinik dalam kelakukan sirkumsisi.

\subsection{Lokasi Kegiatan Pelaksanaan}

Waktu pelaksanaan tanggal 12 bulan September 2019 di di Desa Binaan UMI, Lembang Marinding 
dan Kelurahan Lemo, Kecamatan Mengkendek, Tana Toraja.

\subsection{Metode Kegiatan}

Metode yang digunakan pada pelatihan ini merupakan pelatihan partisipatif, yakni anggota AMSAUMI ikut aktif dalam kegiatan pengabdian sosial. Terlebih dahulu kegiatan dilaksanakan dalam bentuk pelatihan bernama BRAIN sebelum peserta turun langsung ke lokasi. Peserta diberikan materi dan akan dipraktekkan langsung oleh tim instruktur. Kemudian peserta akan dibagi menjadi kelompok kecil untuk menjadi penanggung jawab pada masing-masing kegiatan pengabdian masyarakat termasuk sirkumsisi, Pemeriksaan kesehatan umum, pemeriksaan kandungan USG, serta promosi kesehatan.

\section{HASIL DAN PEMBAHASAN}

Bakti sosial yang diadakan pada hari Kamis, 12 September 2019 di desa binaan UMI di Lembang Marinding, Kecamatan Mengkendek, Kabupaten Tana Toraja telah diadakan dengan beberapa jenis kegiatan dalam rangka pengabdian kepada masyarakat. Adapun jenis kegiatannya ialah sirkumsisi (sunatan), pemeriksaan kesehatan umum, pemeriksaan kandungan USG, serta promosi kesehatan untuk masyarakat desa binaan.

Sirkumsisi atau sunatan adalah prosedur bedah untuk membuang atau memotong kulit yang menutupi penis. Khitan (sunat) adalah salah satu Sunnah fitrah yang sangat dianjurkan bagi seorang muslim dan sebagian ulama berpendapat hukumnya adalah wajib. Sunatan sangat penting dalam hal kesehatan dan kebersihan. Pada kegiatan tersebut kami laksanakan di ruang laboratorium SMP PGRI 1 Marinding dengan memakai 10 meja dengan masing masing operator, asisteren, dan beberapa dokter penanggung jawab disertai ruang resusitasi. Peserta sirkumsisi terdiri dari 36 peserta, rata-rata umur 12 tahun, memiliki rimayat penyakit tipes 1 orang dan mimisan 1 orang, alergi telur 2 orang, alergi daging kerbau 2 orang.

Selain sirkumsisi, juga dilaksanakan pemeriksaan kesehatan umum untuk masyarakat desa binaan yang mau memeriksakan kondisi kesehatannya. Pencegahan lebih baik daripada mengobati, untuk mendeteksi penyakit tahap awal sehingga efektivitas pengobatan dapat segera dilakukan. $(6,7)$ Pemeriksaan kesehatan ini meliputi tes tanda vital seperti tekanan darah, tes laboratorium seperti gula darah, kolesterol dan asam urat juga konsultasi langsung dengan dokter dan juga langsung diberikan obat berdasarkan resep dokter yang telah diberikan. Adapun petugas pemeriksaannya terdiri dari: meja registrasi 2 orang, meja 1 (tekanan darah) 4 orang, meja 2 (pemeriksaan GDS, Kolesterol, Asam Urat) 5 orang, meja 3 (konsultasi dan pemberian obat) 7 orang. Jumlah peserta pemeriksaan kesehatan adalah 164 orang, umur rata-rata 54 tahun.

Pemeriksaan USG atau ultrasonografi biasanya dilakukan untuk memeriksakan segala macam hal yang terkait dengan kehamilan untuk mengetahui jenis kelamin bayi, memantau kondisi bayi dalam kandungan secara keseluruhan, hingga mencari masalah pada tubuh ibu hamil yang bisa merisikokan 
kehamilannya. Jumlah peserta sebanyak 23 orang, umur rata-rata 45 tahun.

Selain sunatan massal dan pemeriksaan kesehatan, juga dilakukan promosi kesehatan yang langsung dibawakan oleh Pembina AMSA UMI yaitu Ayahanda Dr. dr. H. Nasruddin AM, Sp.OG(K), MARS yang membawakan materi bertemakan "Kesehatan Organ Reproduksi" kepada masyarakat yang hadir di acara tersebut. Kegiatan ini dihadiri oleh kurang lebih 100 orang masyarakat desa binaan UMI tersebut. Tingkat kesadaran promosi kesehatan kebijakan, strategi, dan program lainnya masih belum cukup oleh karena itu,program promosi kesehatan di masyarakat secara langsung untuk meningkatkan sistem promosi kesehatan yang ada.(8-10)

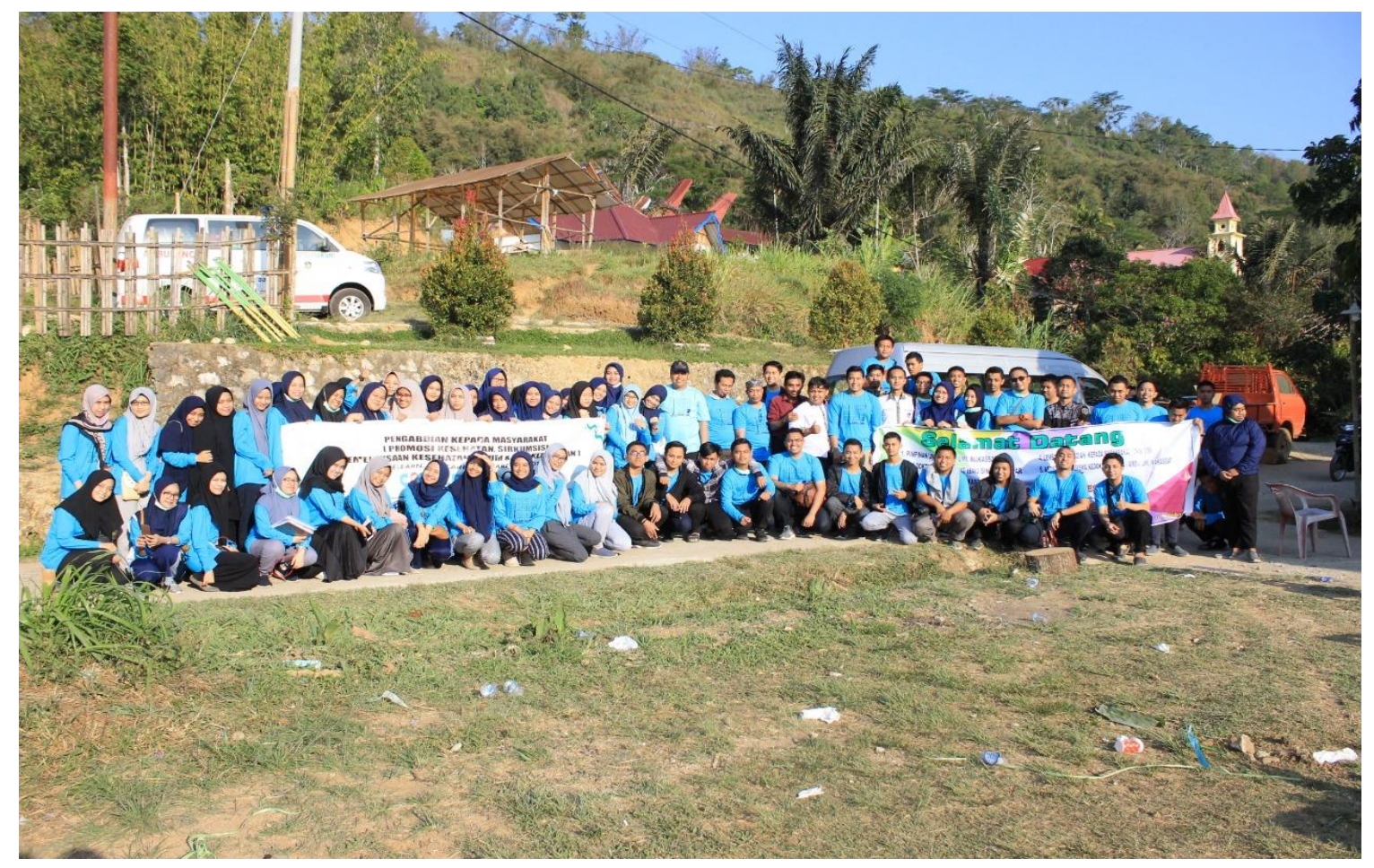

Gambar 1. Foto Pengabdian Masyarakat

\section{KESIMPULAN DAN SARAN}

Kegiatan bakti sosial sebagai penentu sosial kesehatan masyarakat dan juga dapat menjadi wadah bagi mahasiswa untuk dapat berinteraksi secara langsung dengan masyarakat sehingga dapat merealisasikan langsung ilmu yang telah didapatkan dalam perkuliahan ke masyarakat. Bakti sosial yang diadakan pada hari Kamis, 12 September 2019 di desa binaan UMI di Lembang Marinding, Kecamatan Mengkendek, Kabupaten Tana Toraja dengan beberapa jenis kegiatan dalam rangka pengabdian kepada masyarakat berupa sirkumsisi (sunatan), pemeriksaan kesehatan umum, pemeriksaan kandungan USG, serta promosi kesehatan untuk masyarakat desa binaan telah berjalan dengan lancar. Mulai dari tahap persiapan yang telah dibimbing oleh ayahanda pembina AMSA-UMI, kakanda pengurus, kakanda steering, dan kerja keras dari semua panitia. Kegiatan ini diikuti oleh anggota AMSA-UMI, Dosen dan Staf FK UMI, Anggota BEM, Anggota DMP dan Alumni FK UMI. Untuk selanjutnya bisa diadakan lagi bakti sosial di daerah-daerah yang membutuhkan. 


\section{Ucapan Terima Kasih}

Ucapan terima kasih kami kepada ayahanda pembina AMSA-UMI; Dr. dr. Nasrudin A.M., Sp.OG(K), MARS serta dokter-dokter pendamping FK-UMI, pengurus steering, perwakilan DMP, perwakilan BEM, Alumni FK-UMI, dan semua panitia AMSA UMI yang turut membantu dalam pelaksanaan kegiatan pengabdian masyarakat ini.

\section{DAFTAR PUSTAKA}

1. Steketee G, Ross AM, Wachman MK. Health Outcomes and Costs of Social Work Services : A Systematic Review. Am J Public Heal. 2017;107:256-66.

2. Mcgregor J, Mercer SW, Harris FM, Mcgregor J. Health benefits of primary care social work for adults with complex health and social needs : a systematic review. Heal Soc Care Community. 2016;1-13.

3. Mullen EJ, Shuluk J. Outcomes of social work intervention in the context of evidence-based practice. J Soc Work. 2010;11(1):49-63.

4. Golden RL. Coordination, Integration, and Collaboration: A Clear Path for Social Work in Health Care Reform. Heal Soc Work. 2011;36(3):227-8.

5. Hahn R, Truman B. Education improves health and promotes health equality. Int J Heal Serv [Internet]. 2015;45(4):657-78. Available from: https://www.ncbi.nlm.nih.gov/pubmed/25995305

6. Checks NHSH. Health checks and screening: what works in general practice? Br J Gen Pr. 2014;(October):493-500.

7. Rabarison KM, Timsina L, Mays GP. Community Health Assessment and Improved Public Health Decision-Making: A Propensity Score Matching Approach. Am J Public Heal Res. 2015;105(12):2526-33.

8. Pati S, Chauhan AS, Mahapatra S, Sinha R, Pati S. Practicing health promotion in primary care - a reflective enquiry. J Prev Med HYG. 2017;58(2):288-93.

9. Altamimi S, Alshoshan F, Shaman G Al, Tawfeeq N, Alasmary M, Ahmed AE, et al. Health promotion practices as perceived by primary healthcare professionals at the Ministry of National Guard Health Affairs, Saudi Arabia. Qatar Med J. 2016;2016(4):1-9.

10. Kumar S, Gs P. Health Promotion : An Effective Tool for Global Health. Indian J Community Med. 2012;37(3):5-12. 